\title{
Forest Fires Impact on Microclimatic and Soil Conditions in the Forests of Cryolithic Zone (Yakutia, North-Eastern Russia)
}

\author{
(C) 2015 L. P. Gabysheva ${ }^{1,2}$, A. P. Isaev ${ }^{1,3}$ \\ ${ }^{1}$ Institute for Biological Problems of Cryolithozone, \\ Russian Academy of Sciences, Siberian Branch \\ Lenin str., 41, Yakutsk, 677980 Russian Federation \\ ${ }^{2}$ Yakut State Academy of Agriculture \\ Krasilnikov str., 15, Yakutsk, 677980 Russian Federation \\ ${ }^{3}$ Institute of Natural Sciences, North-Eastern Federal University \\ Kulakovsky str., 42, Yakutsk, 677980 Russian Federation \\ E-mail: 1lp77@yandex.ru, forest_forest@ibpc.ysn.ru \\ Received 12.08.2015 г.
}

\begin{abstract}
Data analysis on the fire occurrence and frequency in Central Yakutia (North-Eastern Russia) has been considered. Calculate the impact of socio-economic and climatic conditions of region on inflammability parameters. A close relationship was found between quantity and density of population and the frequency of fires occurence (0.95-0.99). Not so much negative correlation observed between the amount of precipitation during the fire-dangerous period and the frequency of fire $(-0.53)$. The results of our study relating to the fire impact on microclimatic and soil conditions of the forests of Central Yakutia are brought in the article. Studies have revealed that strong changes microclimate and soil conditions in the burnt areas occur in the first 10 years after the fire. At the young burned out site, soil temperature in average increases in comparison with the forest at a depth of $5 \mathrm{~cm}$ in $5.2 \ldots 5.6^{\circ} \mathrm{C}$, at a depth of $30 \mathrm{~cm}-$ in $4.3 \ldots 6.2^{\circ} \mathrm{C}$, soil moisture - by 1.1-2.3 times in a 1-2-year - fire site, by $1.1-1.7$ times in a 10-12-year-old one; seasonally thawed layer thickness is $0.3-0.8 \mathrm{~m}$ greater in the burned out areas than in the forest. There is stabilization of the modified conditions in the post-fire period in the course of succession. Essential changes of microclimatic and soil conditions occurring after fires and stabilizing in the progress of succession when fire-sites overgrow with plants have been found. In the burned areas of the Central Yakutia it starts at the age of 20-25 years after the fire.
\end{abstract}

Keywords: cryolithozone, forest fires, burnt-out areas, fire-site, Yakutia.

How to cite: Gabysheva L. P., Isaev A. P. Forest fires impact on microclimatic and soil conditions in the forests of cryolithic zone (Yakutia, North-Eastern Russia) // Sibirskij Lesnoj Zhurnal (Siberian Journal of Forest Science). 2015. N. 6: 96-111 (in English with Russian abstract).

\section{INTRODUCTION}

One of the most common and destructive factors in the forests of a boreal zone are forest fires. Fires are natural phenomenon in boreal forests (Utkin, 1965; Scherbakov et al., 1979; Sannikov, 1983; Abaimov et al., 1996; Furyaev, 1996; Prokushkin, Zyryanova, 2013 etc). That is why the normal ecological functioning of the forests is determined by fires. Yakutia, one of the largest Russian regions in the North-East, is particularly vulnerable to forest fires (Scherbakov et al., 1979; Yakovlev, 1979; Timofeyev et al., 1994). Over 8.2 thousand fires were recorded in Yakutia during the last 10 years, covering 1.3 million ha and resulting in 20 million $\mathrm{m}^{3}$ of burned out timber (Lytkina, Isaev, 2010). Fires bear both anthropogenic and natural causes of their appearance in the forests of Yakutia. The natural features of the region - combination of permafrost and lack of atmospheric moisture and dry climate - generate natural causes for the emergence and spread of forest fires. The economic development of the region plays an important role in the process of forest-formation in Yakutia. The role of humans in the emergence and spread of forest fires is increasing for the recent years. 
An analysis of the forest fire statistics reveals that the primary cause of forest fires in Yakutia is thunderstorms in July-August (over $50 \%$ ). These are so called «dry thunderstorms», specific for Yakutia. A thunderbolt induces ignition of the ground cover and dead wood. Lightning-caused fires usually affect the largest areas of forest tracts owing to their remoteness and difficulty to access the location. A little less then half of all fires are induced by a man, especially in densely populated and industrial regions. Their amount increases during the intensified recreation periods (agricultural work, spring and autumn hunting, outdoor leisure, harvesting berries and mushrooms, etc.).

In the forests of Yakutia ground (surface) fires are most common. Quick spring fires destroy last year's herbal vegetation, and partly also the fresh tree waste and other dry plant remains, having a minor negative effect on the forest communities. Settled ground fires, however, are more dangerous because of the complete elimination of lower layers, i. e. herbage, shrubs, and young trees. Tree stands remain untouched for $10-90 \%$. After the total or partial destruction of the litter and soilvegetation cover, the heat, moisture, radiation and permafrost conditions of soils change drastically (Utkin, 1965; Pozdnyakov, 1963a, b; Gavrilova, 1967, 1969; Savvinov, 1971; Tarabukina, Savvinov, 1990).

Peculiarity of the burned out forests lies in changes of soil conditions, occurrence of post-fire remains (dead standing and fallen trees) and specifically developing post-fire vegetation.

In the issue of deforestation in the cutting areas and forest fires in burnt-out territories there is an increased access of solar energy and precipitation to soil. It leads to changes in microclimatic and soil conditions on burnt-out areas: temperature and moisture regime of the soil and air (Zyabchenko et al., 1988). And in different natural and climatic areas the vegetative ground cover and therefore fire frequency are different, which causes the difference of soil conditions and features in different forest sites.

Thereupon studying the dynamics of vegetable cover restoration of uneven-aged burnedout forests of the Lena-Amga inter-stream area we found it necessary to observe the change of microclimatic conditions on burnt-out areas after lasting fires among the alases (alas is a closed or semi-closed thermokarst depression developed on upland flat spaces in the area of permafrost distribution (Bosikov, 1991)) where the so called ice complex is widespread.

The aim of this work is to analyze statistical data on forest fires and to study changes in the forest vegetation (microclimate and soil) after the post-fire period.

\section{MATERIALS AND METHODS}

The statistical data on forest fires relates to the period from 1974 to 2011.

We studied the burned out areas of different age: $1-2,10-12,20-23$, and 58-60 for three years (2002-2004). The cowberry larch forest was chosen as a control area - the most prevalent type of the forest of Central Yakutia in East Siberia. Study of microclimate and partly soil indicators on uneven-aged burned-out forest sites (fire-sites) was conducted on the following parameters: air temperature on the soil surface, soil temperature at depths of $5,10,15,20,30$, $40,50,100 \mathrm{~cm}$, air humidity, soil moisture, depth of the seasonally thawed layer (STL) of soil. The standard meteorological (weather) equipment was used: weekly thermographs, hygrographs, mercury and alcohol thermometers (urgent, max, min), Savvinov's knee thermometers, electric thermometer AM-29, sound thermometer probe, balance.

Measurements were carried out in 3 cycles: early in June, mid-July, late in August. Every cycle lasted a week with triple measurements - in the morning (8-9 a. m.), in the day-time (1-2 p. m.), and evening (8-9 p. m.) and additionallyonce per cycle the diurnal measurement with a 3-hour interval was carried out.

Soil studies - soil moisture and the STL depth - were measured once per cycle. Study of soil moisture was conducted with a gravimetric method in three replications at depths of 5, 10, 20, 30, 40, $50 \mathrm{~cm}$ (Rode, 1969).

Data processing is performed using the computer program Excel.

The observations were made in 3 years (20022004) in 4 sites.

The subjects of research are located in the neighborhood of Matta village, MeginoKangalassky ulus (district) of the Sakha (Yakutia) Republic that is $100 \mathrm{~km}$ northeast of Yakutsk the capital of the Republic, in the Lena-Amga 
interfuve, on the right Lena riverside - one of the largest rivers of NE Asia.

A 1-year old fire-site is $7 \mathrm{~km}$ west of Matta vil, Megino-Kangalassky ulus, $200 \mathrm{~m}$ north of Ontoon Toburuone alas. It is a completely burnt out part of the forest with a grassy community of the open type with participation of pioneer species. The microrelief is smooth with occasional thermokarst subsidence. Strong soil overmoisture has been noted. Larch self-sowing is not abundant, annual, 5-7 m high. One hectare of the area comprises 10000 sprouts of Larix cajanderi Mayr and 5000 sprouts of Betula pendula Roth. Chamaenerion angustifolium (L.) Scop. ( $\left.\operatorname{cop}^{3}\right)$ takes prevalence in the herbage. Tephroseris palustris (L.) Reichenb. (sol) grows in the places with moisture excess. Corydalis sibirica (L.) Pers. (sp) and Carex sp. (sol) also occur, while Crepis tectorum L., Vicia cracca L., Limnas stelleri Trin. are single inclusion. Vaccinium vitis-idaea L. and Arctous erythrocarpa (Small) M. Ivanova sprouts are patchy. The total projective cover of herbage averages $50 \%$ in this fire-site. There are favorable conditions (wet soil medium, good light intensity) for pioneer moss species Marchantia polymorpha L. $\left(\operatorname{cop}^{2}\right)$ to grow.

A 10-year old fire-site is located southwest of Matta vil., Megino-Kangalassky ulus on a flat area between Bulgunnyahtah and Keltegeidyah alases. The fire-site is at the stage of motley grass-grasses association with participation of shrubs. The foreststand burntout totally (95\%). Willows-Salix bebbiana Sarg., S. pseudopentandra (B. Floder.) B. Floder., S. pyrolifolia Ledeb., S. viminalis L., $S$. brachypoda (Trautv. et C. A. Mey.) Kom dominate in the young tree growth averaging $1.4 \mathrm{~m}$ high. There is also a young tree growth consisting of Betula pendula Roth and thin Larix cajanderi Mayr. More developed tree growth of Larix cajanderi Mayr occurs in the northern and western part of the fire-site: 40000 young trees/ha, average height $1.8 \mathrm{~m}, 1 \mathrm{~cm}$ in diameter, age $-3-8$ years. The herbaceous-shrub layer is represented by Limnas stelleri Trin. (cop $\left.{ }^{3}\right)$, Rubus arcticus L. $\left(\mathrm{cop}^{2}\right.$ ), Vicia cracca L. (sp), Sanguisorba officinalis L. (sol), Stellaria longifolia Muehl. ex Willd. (sol), Inula britannica L. (sol), Poa pratensis L. (sol), Potentilla anserina L. (sol), occasionally - Chamaenerion angustifolium (L.) Scop., Taraxacum ceratophorum (Ledeb.) DC., Lupinaster pentaphyllus Moench., Equisetum pratense Ehrh., Plantago canescens Adams,
Euphrasia jacutica Juz., Viola mauritii Tepl. and etc., Vaccinium vitis-idaea L. occurs as small patches. The total grassy projective cover attains 70-80\%. Moss-lichen cover is sparse reaching $15 \%$ with prevalence of Marchantia polymorpha L. and occasional Dicranum sp.; lichens present species of the genera Flavocetraria, Cladonia, etc.

A 22-year old fire-site is located $13 \mathrm{~km}$ southwest of Matta vil, Megino-Kangalassky ulus, $100 \mathrm{~km}$ southward of Ulakhan Kuruoleeh alas. The area occupies the southern side of the alas extending further southwest as flat space between alases being at the stage of the birchlarch young trees with sparse herbaceous-shrub cover. Fallen trees are typical, heaps of halfdecayed wood pile up over $90 \%$ of the fire-site area. The young tree growth is very closed and overstocked. Estimation for Larix cajanderi Mayr and Betula pendula Roth is 200000 and 60000 specimen/ha, respectively. Because of the overstocked stand the growth of young trees is inhibited. Larch height averages $1.7 \mathrm{~m}$, lower than $1 \mathrm{~cm}$ in diameter. The maximal tree height attains $3.2 \mathrm{~m}$. The underwood is not developed, willows are occasional. Forest species Vaccinium vitis-idaea L. and Linnaea borealis L. take the leading place in the herbaceous-shrub cover (to $25 \%$ of coverage). Limnas stelleri Trin. (sol) occurs together with suppressed low-sized Chamaenerion angustifolium (L.) Scop.

A 58-year-old fire-site takes an extensive territory from Usun-Ebe alas $(7 \mathrm{~km}$ southwest of Matta vil.) to Mandygytta alas (10 km east of Matta vil.). The site under study is $3 \mathrm{~km}$ southeast of Matta vil. and east of Khatyngnah alas. The microrelief is smooth. The plant carpet is represented by polewood (density $0.6-0.7$ ) with height averaging 7-8 $\mathrm{m}$ and $8.2 \mathrm{~cm}$ in diameter. One hectare holds 1500 larch trees. The young tree growth is uneven subdivided into 2 generations: to $2 \mathrm{~m}$ and from 2 to $4 \mathrm{~m}$ high. The underbrush is not developed. Rosa acicularis Lindl., species from genus Salix occur as single inclusion. The herbaceous-brush belt comprises the forest sp - Vaccinium vitis-idaea L., Linnaea borealis L., Pyrola asarifolia Michaux, Orthilia obtusata (Turcz.) Jutrz. with the total projective cover coming to $80 \%$. Lathyrus humilis (Ser.) Spreng., Limnas stelleri Trin. are also scarce. Moss-lichen cover is composed of Aulacomnium turgidum (Wahlenb.) Schwaegr., Ptilidium ciliare 
(L.). Hampe, Dicranum polysetum Sw., Rhytidium rugosum (Hedw.) Kindb., Peltigera canina (L.) Willd., P. leucophlebia (Nyl.) Gyelu., species from the genus Cladonia.

Cowberry larch is a widespread forest type growing over extensive interstream areas of the frozen taiga pales, weakly solodic loamy soils. The site examined is $1 \mathrm{~km}$ southwest of Matta vil., Megino-Kangalassky ulus, between the Bulgunnyahtah and Keltegyaidyah alases near a 10 -year old fire-site occupying the flat interalas space. Clean or mixed with birch low productive larch stands (70 years old, $12 \mathrm{~m}$ high, $12 \mathrm{~cm}$ in diameter) are typical for it, weakly developed young growth (0.66 ths specimen/ha). In many cases the undershrub layer is absent or Rosa acicularis Lindl., species of the genus Salix scarcely occur. There is a developed continuous cowberry (Vaccinium vitis-idaea L.) carpet with a touch of the forest species (Pyrola asarifolia Michaux, Orthilia obtusata (Turcz.) Jutrz., Linnaea borealis L.) and weakly developed moss-lichen cover of Aulacomnium palustre (Hedw.) Schwaegr., A. turgidum (Wahlenb.) Schwaegr., species of the genera Dicranum, Cladina, Cetraria.

\section{RESULTS AND DISCUSSIONS}

\section{Forest fires in the Lena-Amga interfluves}

According to the information of the Department of Forest Affairs under the Ministry of Nature Protection of the Republic of Sakha (Yakutia), since 1974 to 2011 over 3973 forest fires were recorded in the area embracing 936180 hectares on the territory of the Lena-Amga interfluve. On the average, from 13.5 to 33.9 fires were registered in the area of 1752 to 12900 ha yearly.
Average fire occurrence values of the LenaAmga interfluve forests make $0.403 \%$ over a 38 year period. The data brought in table 1 suggest a significant increase of the relative forest occurrence from 0.013 (1974-1983) to $0.745 \%$ (1994-2003).

Forest fire occurrence changes are shown in Fig. 1, indicating a trend of inflammability growth during the recent years. The statistics are confirmed by a linear trend, which is presented on the graph. Within a 38-year period there were 4 forest fire peaks over this area - in 1987 (1.564\%), 1992 (1.115\%), 2002 (5.39\%) and $2011(2.895 \%) ; 1975$ (0.0005\%), $1976(0.0005$ $\%), 2000(0.0006 \%)$ and $2007(0.0007 \%)$ are characterized as years with minimal forest fire occurrence. Inflammability increase or decrease depends on weather conditions in the present fire hazardous season and it depends more on the precipitation total than on the airtemperature. Thus, years with the maximum fire occurrence (1987, 1992, 2002, 2011) had the minimum precipitation total during the fire hazardous seasons (135.5, 103.0, 82.0 and $153.9 \mathrm{~mm}$, respectively). The tendency of the precipitation total decrease per year is similar to the precipitation total during the fire hazardous season. Table 2 shows the pattern of the regional forest inflammability.

The forests near Yakutsk (20.61 fire cases/100 thousand ha and $0.99 \%$, respectively) and MeginoKangalassy district (5.55 fire cases/100 thousand ha and $0.17 \%$, respectively) are characterized with frequency of forest fires and maximum inflammability. The average area of fires in these regions should be noted as relatively medium and low (2.6 and 1.74 thousand ha, respectively), the reason for that is early detection of fire and timely fire extinguishing owing to high density of population (63 persons per square $\mathrm{km}$ ) and

Table 1. Forest fire occurrence in the districts of the Lena-Amga interfluve and in Yakutsk environs, \%

\begin{tabular}{|c|c|c|c|c|c|c|c|}
\hline \multirow[b]{2}{*}{ Years } & \multicolumn{6}{|c|}{ Districts of Central Yakutia } & \multirow{2}{*}{$\begin{array}{c}\text { Average over } \\
\text { the whole } \\
\text { area }\end{array}$} \\
\hline & Amga & $\begin{array}{c}\text { Megino- } \\
\text { Kangalassy }\end{array}$ & Tatta & Ust-Aldan & Churapcha & Yakutsk & \\
\hline 1974-1983 & 0.012 & 0.016 & 0.022 & 0.005 & 0.003 & 0.022 & 0.013 \\
\hline 1984-1993 & 0.199 & 0.132 & 0.760 & 0.183 & 0.016 & 0.633 & 0.320 \\
\hline 1994-2003 & 0.159 & 0.341 & 0.091 & 0.171 & 0.572 & 3.138 & 0.745 \\
\hline 2004-2011 & 1.721 & 0.202 & 0.434 & 0.072 & 0.566 & 0.199 & 0.532 \\
\hline $\begin{array}{c}\text { Average over } \\
1974-2011\end{array}$ & 0.523 & 0.173 & 0.327 & 0.108 & 0.289 & 0.998 & 0.403 \\
\hline
\end{tabular}

Note. Fire occurrence is a fire-total area ratio in $\%$. 


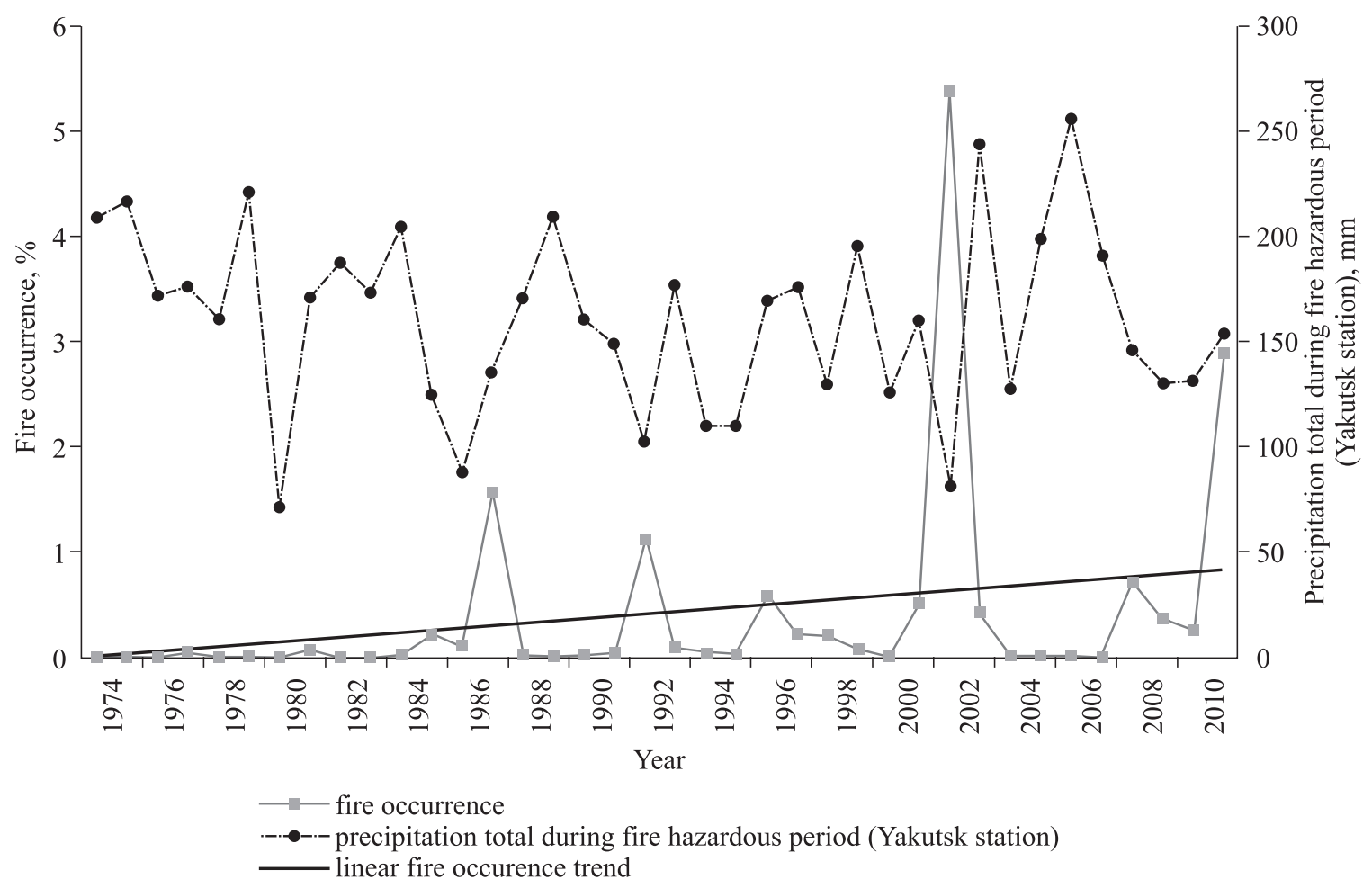

Fig. 1. Dependency of the relative forest fire occurrence on precipitation total in the Lena-Amga interfluves.

Table 2. Characteristic of forest fire occurrence in the Lena Amga interfluve and in Yakutsk environs

\begin{tabular}{l|c|c|c|c|c|c}
\hline \multicolumn{1}{c|}{ Districts } & Amga & $\begin{array}{c}\text { Megino- } \\
\text { Kangalassy }\end{array}$ & Tatta & Ust-Aldan & Churapcha & Yakutsk \\
\hline Fire frequency, case/100 thou ha & 1.46 & 5.55 & 1.55 & 2.84 & 2.65 & 20.61 \\
Fire occurrence, \% & 0.52 & 0.17 & 0.33 & 0.11 & 0.29 & 0.99 \\
Average area of fire, thou ha & 12.90 & 1.74 & 5.45 & 1.75 & 2.97 & 2.60
\end{tabular}

developed forest areas. The most favorable in the context of fire breaking out areas are Amga and Tatta districts - less than 2 fires per fire hazardous season. But the average fire area in these regions is the highest - about 5.45-12.9 thousand ha owing to vast unexplored forest areas.

Table 3. Forest fire occurrence and socio-economic and climatic conditions relationship

\begin{tabular}{l|c}
\hline \multicolumn{1}{c|}{ Indices } & $\begin{array}{c}\text { Correlation } \\
\text { coefficient }\end{array}$ \\
\hline Density of population - fire occurrence & 0.99 \\
Density of population - fire frequency & 0.95 \\
Population abundance - fire occurrence & 0.99 \\
Population abundance - fire frequency & 0.96 \\
Precipitation total per fire hazardous & -0.53 \\
period - fire frequency & \\
Average air temperature per fire hazardous & -0.17 \\
period - fire frequency &
\end{tabular}

According to the data collected, correlation coefficients of inflammability indices were calculated considering some climatic and socioeconomic conditions (Table 3).

Relation between abundance and density of population with fire occurrence statistics and frequency is expressed by a correlation coefficient 0.95-0.99 that evidences a close relationship among these indices. Correlation coefficient between precipitation total per fire hazardous period and frequency of fire indicates the existing negative relation $(-0.53)$ though it is not very significant. There is no any relationship between the average air temperature and fire frequency $(-0.17)$.

Data analysis on the cause of fire breaking out for a 38-year period on Lena-Amga interfluve revealed (Fig. 2) that the main reason of fires are «dry thunderstorms» in July-August (38.3\%). 


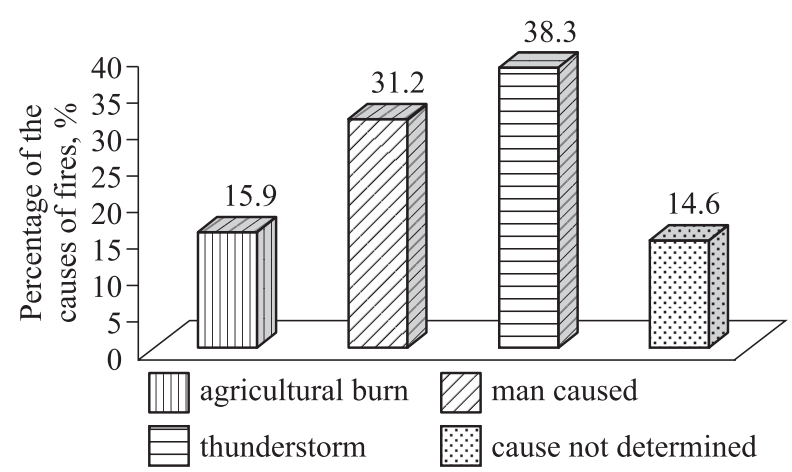

Fig. 2. Causes of fire in the forests of Lena-Amga interfluve and near the city of Yakutsk, in \% from the total number.

$15.9 \%$ of fires falls on the agricultural burns, a traditional method of pasture preparation in cattle-breeding regions of Yakutia. 31.2\% of fire accidents happen because of casual handling with fire. During recent years a man-caused share of fires has significantly increased. Only in 2002 $70.42 \%$ of fires were man-caused. There are also fire cases the origin of which was not determined $(14.6 \%)$.

Thus, there always were forest fires in Central Yakutia causing direct or indirect influence on forest ecosystems. Though we did not consider the forest fires statistics at the beginning of the last century, there is reason to believe that forest fires always took place in Central Yakutia and had an influence on the wildlife.

In comparison with the other regions of Yakutia, Central regions have been characterized by particularly high forest inflammability for a long historical time, by reason of not only arid conditions and high density of population but also because of a housekeeping habit in these regions. Agricultural burning of grasslands, pastures and hayfields used to be the main cause of forest fires until recently (Utkin, 1965).

It seems practically impossible to prevent fire breaking out in the permafrost regions which are difficult to take under control by the special forest fire protection services because under weak decomposition of plant litter and deficient mineralization of organic matter in the soil, accumulation of inflammable materials in the forests of the permafrost regions is enough to be the source of forest fire emergence during the arid seasons of the year (Tarabukina, Savvinov, 1990). Forest fires tend to a definite cyclic emergence relating to the climate changeability each year that is particularly clearly expressed in central arid regions of Yakutia (Utkin, 1965; Yakovlev, 1979; Scherbakov et al., 1979; Isaev et al., 2004).

\section{Fire impact on the microclimatic and soil conditions}

According to the literature data, all changes in microclimatic and soil conditions depend on changes of the radiation situation in the forest after a fire. In the issue of deforestation and forest fires an inflow of light into the forest floor is increasing (Gavrilova, 1967, 1969; Isaev, 1993; etc). For example, according to M. K. Gavrilova (1973), in Central Yakutia $56 \mathrm{kcal} / \mathrm{cm}^{2}$ of total radiation penetrates through the crown layer of the larch forests and on the open space it is about $90-100 \mathrm{kcal} / \mathrm{cm}^{2}$ of heat per year. The major part of luminous flux $(54.8-69.5 \%)$ in the forest is blocked by tree crowns. And the greater is the canopy closure, the lower is illumination (8-9\% with each point) (Scherbakov et al., 1979; Isaev, 1993). Besides, the reflecting power of the forest cover amounts to $20 \%$, while reflectance of dark surface of burnt out spot amounts to $10 \%$ (Gavrilova, 1969).

Fire impact on the ambient temperature. Air temperature measurement is carried out on the soil surface level, where main biological processes occur (from forest fires to plant growth and death).

The temperature conditions of the studied areas are characterized by figures given in Table 4 .

The table shows average ten-day (decade) means of the air temperature observed at 8 a. m., 2 and $8 \mathrm{p} . \mathrm{m}$. in the beginning, middle and end of the vegetation period.

Temperature observations in the fire sites showed that the ambient temperature is slightly higher as compared to the one in the control area in the cowberry larch (hereinafter-in the forest). Thus, in 2002-2003, the surface layer of air on burned out areas was warmer than in the forest, by $1.2-1.4{ }^{\circ} \mathrm{C}$ in July, by $0.6-1.1{ }^{\circ} \mathrm{C}$ in August. The analysis of the diurnal temperature range on the soil surface during the vegetation periods has revealed the following. In the beginning of the vegetation period (06.06.2004-10.06.2004) sizeable fluctuation of the diurnal temperature range has been detected (Fig. 3, a). For lack of any vegetation and less shading during the daytime the air temperature in burnt-out areas is much higher 
Table 4. Air-ground temperatures in the burned-out areas and in the forest, ${ }^{\circ} \mathrm{C}$

\begin{tabular}{|c|c|c|c|c|c|c|c|c|}
\hline \multirow{2}{*}{ Year } & \multirow{2}{*}{ Site } & \multirow{2}{*}{$\begin{array}{l}\text { Observation time } \\
\text { (month, decade) }\end{array}$} & \multicolumn{3}{|c|}{ Observation period } & \multirow{2}{*}{$\begin{array}{l}\text { Average } \\
\text { aily }\end{array}$} & \multicolumn{2}{|c|}{ The average } \\
\hline & & & $8: 00$ & $14: 00$ & $20: 00$ & & $\min$ & $\max$ \\
\hline \multirow{8}{*}{2002} & \multirow[t]{2}{*}{ Fresh burnt-out areas } & II decade of July & 19.4 & 23.4 & 21.2 & 21.3 & 11.7 & 27.7 \\
\hline & & III decade of August & 10.0 & 18.7 & 14.6 & 14.5 & 6.0 & 19.9 \\
\hline & \multirow[t]{2}{*}{10 year burnt-out areas } & II decade of July & 19.8 & 24.3 & 0.3 & 21.5 & 11.2 & 29.2 \\
\hline & & III decade of August & 10.1 & 19.0 & 15.8 & 15.0 & 7.9 & 20.1 \\
\hline & \multirow[t]{2}{*}{58 year burnt-out areas } & II decade of July & 17.8 & 22.9 & 19.7 & 20.1 & 12.3 & 25.1 \\
\hline & & III decade of August & 7.7 & 15.9 & 12.0 & 11.9 & 6.1 & 16.8 \\
\hline & \multirow[t]{2}{*}{ Cowberry larch } & II decade of July & 18.5 & 21.9 & 19.9 & 20.1 & 10.8 & 24.9 \\
\hline & & III decade of August & 9.6 & 18.0 & 14.3 & 13.9 & 8.0 & 18.4 \\
\hline \multirow{6}{*}{2003} & \multirow[t]{2}{*}{10 year burnt-out areas } & II decade of July & 19.7 & 30.7 & 22.3 & 24.2 & 12.8 & 34.0 \\
\hline & & III decade of August & 7.6 & 18.3 & 13.5 & 13.9 & 6.6 & 20.0 \\
\hline & \multirow[t]{2}{*}{58 year burnt-out areas } & II decade of July & 13.8 & 28.2 & 24.5 & 22.2 & 11.5 & 33.0 \\
\hline & & III decade of August & 6.5 & 16.5 & 14.0 & 12.3 & 6.8 & 17.8 \\
\hline & \multirow[t]{2}{*}{ Cowberry larch } & II decade of July & 19.7 & 30.0 & 26.5 & 25.4 & 14.7 & 32.8 \\
\hline & & III decade of August & 9.5 & 16.5 & 10.7 & 12.1 & 6.3 & 17.7 \\
\hline
\end{tabular}

$\left(22^{\circ} \mathrm{C}\right)$ than in the forest $\left(20^{\circ} \mathrm{C}\right)$. In the nighttime it falls below zero as a result of cooling of the open territory in the burnt-out area.

In the middle of the vegetation period (11.07$16.072004)$ the air temperature becomes warmer in burnt-out area in the nighttime (Fig. 3, $b$ ) and the difference of the average minimum temperatures between burnt-out areas and the forest is in the range of $0.4-0.9^{\circ} \mathrm{C}$. That is likely connected with heat loss accumulated during the day by crowns of trees and for want of the air turbulent mixing.

In the end of the vegetation period (26.0830.082004 ) the average air temperature both in the burnt-out areas and forest becomes almost equal at the expense of the daytime temperature reduction (up to $24^{\circ} \mathrm{C}$ ), and the nighttime temperature does not fall below zero yet (Fig. 3, c). However, the temperature on burnt-out areas is lower than in the forest by $0.5-2{ }^{\circ} \mathrm{C}$. It is explained by the turbulent heat exchange (Savvinov, 1971), which intensifies in the nighttime in the open spaces. In cloudy weather, as known (Tarabukina, Savvinov, 1990) the temperatures in burnt-out areas and in the forest become smooth according to the data of 15.07.2004 and 28.08.2004. On August 27 maximum temperature fluctuation was detected in a 10-year burnt-out area: in the daytime at 4 p. m. the highest air temperature was $24^{\circ} \mathrm{C}$ and in nighttime at $5 \mathrm{a} . \mathrm{m}$. the lowest temperature was $11.1^{\circ} \mathrm{C}$

Fire impact on soil temperature. During the whole vegetative period the soil temperature in the burned out sites was much higher than in the forest. And the highest temperature was noted on the young burn site (Table 5 and 6).

Thus, the soil temperature in a 2 -year burntout area at a depth of $5 \mathrm{~cm}$ early in the vegetation period was higher than in the forest by $5.5^{\circ} \mathrm{C}$ and by $3.1{ }^{\circ} \mathrm{C}$ than in a 12 -year burnt-out area (Table 6). The average temperature in the midvegetation period in a 1-2-year burnt-out area at the same depth was $15.8{ }^{\circ} \mathrm{C}$, in a $10-12$-year burnt-out area $-17.4{ }^{\circ} \mathrm{C}$ and in the forest $13.1{ }^{\circ} \mathrm{C}$ (Table 5).

This sizeable warming up may be caused by ability of black surface to absorb solar rays, as reflective capacity of the dark surface of bonfire sites is much lower than the forest floor (10 and $2 \%$, respectively; Gavrilova, 1969).

Therewith, reduction of shading ability of tree crowns assists insolation. Maximum rising of soil temperature was observed in the middle of the vegetative period. It is known that in Central Yakutia the temperature of the open soil surface is two times higher than in the forest (Gavrilova, 1973).

Shading of the soil surface by plants increases as the burning grows over in process of succession and thus reduces penetration of direct sunlight resulting in a gradual soil temperature decrease.

According to the observation by M. K. Gavrilova (1967) made near Lake Tyungyulyu (Megino-Kangalassky ulus), which is situated in the neighborhood of our research objects $(25-30 \mathrm{~km})$, 

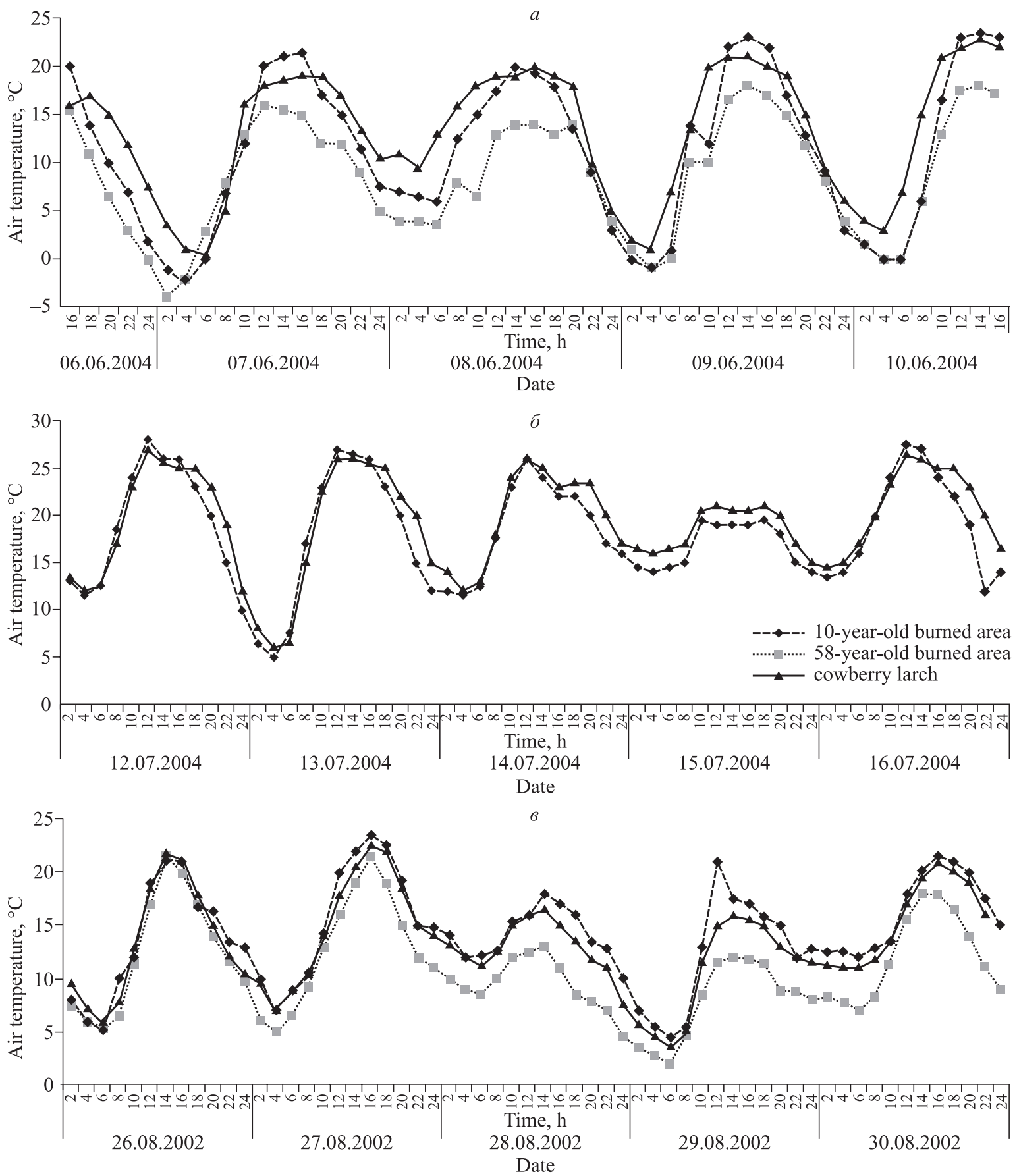

Fig. 3. Diurnal variation of the air temperature on the soil surface in burnt-out areas and the forest early in, middle and late in the vegetation period: $a-06.06 .2004 ; b-11.07-16.07 .2004 ; c-26.08-30.08 .2002$.

the soil negative temperatures at the depth of 50 $\mathrm{cm}$ beneath the larch remain till mid-June. Our three years' observations showed that they remain at the same depth of $50 \mathrm{~cm}$ (beneath the larch) till mid-July. From our point of view, it depends on the density of tree crowns in this forest site and on weather conditions of the definite year of research.

As a rule, the greatest rise of soil temperature is observed in the upper layers of soil pro- file in the «young» burnt-out areas. Table 6 show, that soil temperature was higher by $3.1 \ldots 5.5{ }^{\circ} \mathrm{C}$ at the depth of $5 \mathrm{~cm}$ in the burnt-out site early in the vegetation period (early June), and by $1.4 \ldots 1.7^{\circ} \mathrm{C}$ at the depth of $50 \mathrm{~cm}$ than soil temperature under the forest canopy. The maximum temperature rise is observed in the middle of the vegetation period. The temperature difference between the burnt-out area and forest at the depth of $5 \mathrm{~cm}$ is $5.2 \ldots 5.6^{\circ} \mathrm{C}$, and at the depth of $50 \mathrm{~cm}-$ 
Table 5. Average soil temperature $\left({ }^{\circ} \mathrm{C}\right)$ at different depths and in different periods of vegetation

\begin{tabular}{|c|c|c|c|c|c|c|c|c|c|c|}
\hline \multirow{2}{*}{ Observation time } & \multirow{2}{*}{ Site } & \multicolumn{9}{|c|}{ Depth, cm } \\
\hline & & 5 & 10 & 15 & 20 & 30 & 40 & 50 & 80 & 100 \\
\hline \multirow{4}{*}{ II decade of July 2002} & Fresh burned area & 13.6 & 12.6 & 11.3 & 10.8 & 7.7 & 6.5 & 4.6 & 0.5 & -0.2 \\
\hline & 10-year-old burned area & 16.3 & 15.4 & 14.9 & 14.3 & 13.3 & 12 & 9.8 & 7.3 & 4.1 \\
\hline & 58-year-old burned area & 14.4 & 13.7 & 12.7 & 11.7 & 11.1 & 8.9 & 7.3 & 2.2 & 0.1 \\
\hline & Cowberry larch & 12.3 & 11.0 & 9.6 & 7.7 & 3.5 & 2.5 & 0.1 & - & - \\
\hline \multirow{4}{*}{ III decade of August 2002} & Fresh burned area & 8.5 & 7.6 & 7.2 & 6.9 & 3.5 & 3.2 & 2.5 & 1.0 & 0.1 \\
\hline & 10-year-old burned area & 12.1 & 10.8 & 10.0 & 9.5 & 8.9 & 8.1 & 6.9 & 4.9 & 3.2 \\
\hline & 58-year-old burned area & 10.2 & 9.5 & 8.5 & 7.7 & 6.5 & 4.8 & 3.6 & 1.2 & 0.1 \\
\hline & Cowberry larch & 7.8 & 7.2 & 6.3 & 5.2 & 3.0 & 2.0 & 0.8 & - & - \\
\hline \multirow{3}{*}{ II decade of July 2003} & 11-year-old burned area & 18.0 & 17.1 & 16.2 & 15.9 & 14.2 & 12.7 & 9.7 & 4.2 & 2 \\
\hline & 59-year-old burned area & 16.6 & 15.5 & 14.3 & 13.2 & 7.3 & 5.4 & 2.8 & 0.3 & - \\
\hline & Cowberry larch & 14.6 & 12.3 & 11.5 & 8.2 & 6.5 & 4.5 & 0.6 & - & - \\
\hline \multirow{3}{*}{ III decade of August 2003} & 11-year-old burned area & 9.1 & 8.6 & 8.4 & 8.4 & 6.6 & 5.7 & 4.7 & 3.3 & 1.7 \\
\hline & 59-year-old burned area & 9.0 & 8.4 & 7.5 & 6.8 & 3.9 & 2.9 & 2.0 & 1.2 & - \\
\hline & Cowberry larch & 9.7 & 8.2 & 7.8 & 7.6 & 5.2 & 4.0 & 3.5 & 1.9 & 0.7 \\
\hline \multirow{4}{*}{ I decade of June 2004} & 2-year-old burned area & 12.1 & 10.2 & 9.6 & 7.7 & 3.8 & 2.1 & -0.2 & -2.6 & - \\
\hline & 12-year-old burned area & 9.7 & 8.4 & 8.0 & 6.0 & 2.0 & 0.7 & -0.5 & -1.8 & -3.3 \\
\hline & 60- years-old burned area & 7.6 & 6.3 & 4.3 & 3.8 & -0.4 & -0.9 & -1.2 & -2.4 & - \\
\hline & Cowberry larch & 6.6 & 6.0 & 5.0 & 3.6 & 0.6 & -0.7 & -1.9 & -4 & - \\
\hline \multirow{4}{*}{ II decade of July 2004} & 2-year-old burned area & 18.0 & 17.0 & 14.7 & 12.5 & 10.2 & 8.9 & 7.8 & 5.2 & 0.3 \\
\hline & 12-year-old burned area & 17.6 & 16.8 & 16.8 & 14.6 & 12.1 & 10.1 & 8.4 & 2.8 & 0.6 \\
\hline & 60-year-old burned area & 13.7 & 11.2 & 10.1 & 10.7 & 4.0 & 2.6 & 0.2 & -1.0 & - \\
\hline & Cowberry larch & 12.4 & 12.0 & 10.5 & 9.9 & 5.9 & 3.0 & 0.0 & -1.1 & - \\
\hline
\end{tabular}

Table 6. Temperature difference in soils of burned out areas and nature forest (cowberry larch) at different depths, ${ }^{\circ} \mathrm{C}$

\begin{tabular}{|c|c|c|c|c|c|c|c|c|c|c|}
\hline \multirow{2}{*}{ Observation time } & \multirow{2}{*}{ Comparison sites } & \multicolumn{9}{|c|}{ Depth, cm } \\
\hline & & 5 & 10 & 15 & 20 & 30 & 40 & 50 & 80 & 100 \\
\hline \multirow{3}{*}{ I decade of June 2004} & $\begin{array}{l}\text { 2-year-old burned area - } \\
\text { cowberry larch }\end{array}$ & 5.5 & 4.2 & 4.6 & 4.1 & 3.2 & 2.8 & 1.7 & 1.4 & - \\
\hline & $\begin{array}{l}\text { 12-year-old burned area } \\
\text {-cowberry larch }\end{array}$ & 3.1 & 2.4 & 3.0 & 2.4 & 1.4 & 1.4 & 1.4 & 2.2 & - \\
\hline & $\begin{array}{c}\text { 60-years-old burned area - } \\
\text { cowberry larch }\end{array}$ & 1.0 & 0.3 & -0.7 & 0.2 & -1.0 & -0.2 & 0.7 & 1.6 & - \\
\hline \multirow{3}{*}{ II decade of July 2004} & $\begin{array}{l}\text { 2-year-old burned area - } \\
\text { cowberry larch }\end{array}$ & 5.6 & 5.0 & 4.2 & 2.6 & 4.3 & 5.9 & 7.8 & 6.3 & - \\
\hline & $\begin{array}{c}\text { 12- year-old burned area - } \\
\text { cowberry larch }\end{array}$ & 5.2 & 4.8 & 6.3 & 4.7 & 6.2 & 7.1 & 8.4 & 3.9 & - \\
\hline & $\begin{array}{c}\text { 60- year-old burned area - } \\
\text { cowberry larch }\end{array}$ & 1.3 & -0.8 & -0.4 & 0.8 & -1.9 & -0.4 & 0.2 & 0.1 & - \\
\hline \multirow{3}{*}{ III decade of August 2004} & $\begin{array}{l}\text { 2- year-old burned area - } \\
\text { cowberry larch }\end{array}$ & 1.9 & 2.1 & 2.3 & 1.5 & 1.3 & 2.5 & 5.0 & 2.9 & - \\
\hline & $\begin{array}{l}\text { 12- year-old burned area } \\
\text {-cowberry larch }\end{array}$ & 1.9 & 2.4 & 3.0 & 2.2 & 2.0 & 2.9 & 5.5 & 2.6 & - \\
\hline & $\begin{array}{c}\text { 60- year-old burned area- } \\
\text { cowberry larch }\end{array}$ & 1.0 & 0.4 & -0.2 & 0.7 & -1.4 & -0.2 & -0.1 & -0.4 & - \\
\hline
\end{tabular}


Table 7. Diurnal soil temperature range in uneven-aged fire-sites and in the forest (as of 7.07.2002)

\begin{tabular}{|c|c|c|c|c|c|c|c|c|c|}
\hline \multirow{2}{*}{ Sites } & \multirow{2}{*}{$\begin{array}{l}\text { Measuring } \\
\text { depth }\end{array}$} & \multicolumn{8}{|c|}{ Soil temperature, ${ }^{\circ} \mathrm{C}$, at various time of day, hours } \\
\hline & & $8: 00$ & $11: 00$ & $14: 00$ & $17: 00$ & $20: 00$ & 23:00 & $2: 00$ & $5: 00$ \\
\hline \multirow[t]{9}{*}{ Fresh-fire-site } & 5 & 11.2 & 12.5 & 13.7 & 13.8 & 12.3 & 12 & 11.4 & 9.6 \\
\hline & 10 & 10.8 & 11.2 & 12.4 & 12.4 & 11.9 & 11.3 & 10.5 & 9.4 \\
\hline & 15 & 10.6 & 10.8 & 11 & 11.2 & 11.1 & 10.9 & 10.3 & 9.7 \\
\hline & 20 & 10.5 & 10.5 & 10.4 & 10.6 & 10.6 & 10.5 & 10 & 9.7 \\
\hline & 30 & 6.8 & 6.8 & 6.9 & 6.9 & 6.5 & 6 & 5.8 & 5.6 \\
\hline & 40 & 5.3 & 5.3 & 5.4 & 5.3 & 5 & 4.6 & 4.6 & 4.5 \\
\hline & 50 & 2.8 & 3 & 3.4 & 3.3 & 3.1 & 2.9 & 2.8 & 2.7 \\
\hline & 80 & -0.1 & -0.1 & 0 & 0 & 0 & -0.2 & -0.2 & -0.3 \\
\hline & 100 & -0.7 & -0.6 & -0.4 & -0.6 & -0.5 & -0.8 & -0.7 & -0.6 \\
\hline \multirow[t]{9}{*}{ 10-year old fire-site } & 5 & 12.7 & 14.0 & 15.0 & 15.7 & 15.2 & 15.8 & 12.5 & 10.8 \\
\hline & 10 & 12.7 & 13.2 & 13.8 & 14.6 & 14.6 & 13.7 & 12.6 & 11.5 \\
\hline & 15 & 12.7 & 13.0 & 13.3 & 14.2 & 14.3 & 13.6 & 12.8 & 11.9 \\
\hline & 20 & 13.0 & 13.0 & 13.0 & 13.5 & 13.7 & 13.5 & 13.0 & 12.5 \\
\hline & 30 & 12.5 & 12.5 & 12.3 & 12.4 & 12.4 & 12.4 & 12.3 & 12.2 \\
\hline & 40 & 11.2 & 11.2 & 11.2 & 11.3 & 11.3 & 11.0 & 11.0 & 10.9 \\
\hline & 50 & 9.4 & 9.4 & 9.5 & 9.3 & 9.3 & 8.5 & 8.5 & 8.6 \\
\hline & 80 & 6.6 & 6.8 & 7.0 & 6.6 & 6.5 & 6.4 & 6.3 & 6.2 \\
\hline & 100 & 3.0 & 3.5 & 3.8 & 3.2 & 3.3 & 2.8 & 2.8 & 2.8 \\
\hline \multirow[t]{9}{*}{ 58-year old fire-site } & 5 & 12.4 & 12.8 & 13.3 & 13.4 & 13.5 & 13.0 & 12.0 & 10.6 \\
\hline & 10 & 12.3 & 12.5 & 12.7 & 12.9 & 13.2 & 12.8 & 11.6 & 11.0 \\
\hline & 15 & 12.1 & 12.1 & 12.0 & 12.2 & 12.3 & 12.0 & 11.4 & 10.9 \\
\hline & 20 & 11.3 & 11.2 & 11.1 & 11.1 & 11.2 & 11.1 & 10.7 & 10.3 \\
\hline & 30 & 10.2 & 10.2 & 10.2 & 10.1 & 10.0 & 9.9 & 9.6 & 9.4 \\
\hline & 40 & 8.2 & 8.4 & 8.6 & 8.5 & 8.3 & 7.7 & 7.8 & 7.9 \\
\hline & 50 & 6.0 & 6.3 & 6.7 & 6.8 & 6.9 & 5.5 & 5.5 & 5.5 \\
\hline & 80 & 1.1 & 1.3 & 1.5 & 1.5 & 1.5 & 1.3 & 1.2 & 1.2 \\
\hline & 100 & -0.9 & -0.7 & -0.2 & -0.2 & -0.3 & -0.5 & -0.5 & -0.5 \\
\hline \multirow[t]{7}{*}{ Cowberry larch (Forest) } & 5 & 8.1 & 9.5 & 10.4 & 10.6 & 9.8 & 9.3 & 7.5 & 6.7 \\
\hline & 10 & 8.0 & 8.3 & 8.7 & 9.0 & 9.0 & 8.7 & 7.9 & 7.2 \\
\hline & 15 & 7.1 & 7.1 & 7.2 & 7.6 & 7.6 & 7.6 & 7.0 & 6.5 \\
\hline & 20 & 5.4 & 5.5 & 5.6 & 5.7 & 5.7 & 5.6 & 5.6 & 5.0 \\
\hline & 30 & 2.0 & 2.2 & 2.3 & 2.2 & 1.9 & 1.8 & 1.7 & 1.7 \\
\hline & 40 & 1.0 & 1.0 & 1.0 & 1.3 & 0.9 & 0.8 & 0.7 & 0.7 \\
\hline & 50 & -0.1 & 0.0 & 0.0 & 0.0 & -0.1 & -0.3 & -0.3 & -0.4 \\
\hline
\end{tabular}

7.8...8.4 ${ }^{\circ} \mathrm{C}$. It indicates that during the nighttime the upper layers of soil manage to use up the heat that was accumulated in the daytime whereas the lower layers fail to do it. The absence of the forest canopy and black surface of soil on a 1-year burnt-out site facilitates the greater heat emission at nighttime. In the end of the vegetation period the difference between burnt-out areas and the forest is decreasing. At the depth of $5 \mathrm{~cm}$ the difference is only about $1.9{ }^{\circ} \mathrm{C}$ whereas at the depth of $50 \mathrm{~cm}$ it is about $5.0 \ldots .5 .5^{\circ} \mathrm{C}$. The phenomenon of the least heat loss at nighttime is particularly evident by the end of the vegetation period.
The analysis of the variance in a daily temperature of the soil showed the greater increasing between $14.00-15.00$, the smaller - at 5 a. m. (Table 7).

Fire impact on soil moisture. Changes in temperature and freezing conditions of soils in the post-fire periods also affect soil moisture. Taking into account that the great bulk of roots of woody and other plants is in a half-meter soil layer (Pozdnyakov, 1963a; Dokhunaev, 1963, 1988 etc.), soil moisture measurement was carried out up to a depth of $50 \mathrm{~cm}$. Calculations showed that it increases mainly in the beginning 
Table 8. Field soil moisture at different depths in the burned areas and in the control forest in 2002-2003, $\%$ of dry weight

\begin{tabular}{|c|c|c|c|c|c|c|c|c|c|c|}
\hline \multirow{4}{*}{$\begin{array}{c}\text { Depth, } \\
\mathrm{cm}\end{array}$} & \multicolumn{5}{|c|}{ July } & \multicolumn{5}{|c|}{ August } \\
\hline & \multicolumn{10}{|c|}{2002} \\
\hline & \multicolumn{4}{|c|}{ The age of burned area } & \multirow{2}{*}{ Forest } & \multicolumn{4}{|c|}{ The age of burned area } & \multirow{2}{*}{ Forest } \\
\hline & $0-1$ & $10-11$ & $21-22$ & $58-59$ & & $0-1$ & $10-11$ & $21-22$ & $58-59$ & \\
\hline $5 \mathrm{~cm}$ & 12.9 & 18.1 & - & 9.8 & 14.0 & 26.8 & 17.7 & - & 14.6 & 14.5 \\
\hline $10 \mathrm{~cm}$ & 15.9 & 20.1 & - & 7.3 & 15.1 & 20.2 & 17.2 & - & 13.0 & 15.7 \\
\hline $20 \mathrm{~cm}$ & 17.0 & 18.1 & - & 10.8 & 15.1 & 20.6 & 20.7 & - & 13.9 & 18.9 \\
\hline & \multicolumn{10}{|c|}{2003} \\
\hline $5 \mathrm{~cm}$ & 15.45 & 17.1 & - & 9.0 & 21.8 & 25 & 21.4 & 15.5 & 14.2 & 21.9 \\
\hline $10 \mathrm{~cm}$ & 19.3 & 15.5 & - & 9.9 & 17.9 & 21.5 & 19.9 & 12.3 & 14.6 & 15.5 \\
\hline $20 \mathrm{~cm}$ & 22.7 & 17.4 & - & 11.3 & 17.1 & 23.4 & 16.7 & 8.5 & 10.5 & 13.8 \\
\hline $30 \mathrm{~cm}$ & 23.4 & 19.3 & - & 17.1 & 16.0 & 25.4 & 19.1 & 8.6 & 10.4 & 11.5 \\
\hline $50 \mathrm{~cm}$ & 22.3 & 18.0 & - & 11.1 & 17.9 & 23.3 & 19.0 & 12.9 & 10.4 & 15.2 \\
\hline
\end{tabular}

Table 9. Field soil moisture at different depths in the burned areas and in the control forest in 2004,

$\%$ of dry weight

\begin{tabular}{|c|c|c|c|c|c|c|c|c|c|c|c|c|c|c|c|}
\hline \multirow{3}{*}{$\begin{array}{c}\text { Depth, } \\
\text { cm }\end{array}$} & \multicolumn{5}{|c|}{ June } & \multicolumn{5}{|c|}{ July } & \multicolumn{5}{|c|}{ August } \\
\hline & \multicolumn{4}{|c|}{ The age of burned area } & \multirow{2}{*}{ Forest } & \multicolumn{4}{|c|}{ The age of burned area } & \multirow{2}{*}{ Forest } & \multicolumn{4}{|c|}{ The age of burned area } & \multirow{2}{*}{ Forest } \\
\hline & 2 & 12 & 23 & 60 & & 2 & 12 & 23 & 60 & & 2 & 12 & 23 & 60 & \\
\hline $5 \mathrm{~cm}$ & 33.7 & 24 & - & 24.8 & 39.9 & 20.7 & 19.5 & 4.6 & 6.6 & 29.6 & 31.5 & 21.2 & 15.2 & 11.6 & 13.6 \\
\hline $10 \mathrm{~cm}$ & 33.1 & 21.1 & - & 26.2 & 26.4 & 29.0 & 15.2 & 6.2 & 7.3 & 20.2 & 21.2 & 17.2 & 14.8 & 9.4 & 15.5 \\
\hline $20 \mathrm{~cm}$ & 36.9 & 20.5 & - & 18.7 & 24.7 & 20.3 & 13.2 & 8.3 & 6.1 & 14.7 & 20.4 & 17.3 & 12.9 & 10.4 & 14.2 \\
\hline $30 \mathrm{~cm}$ & 28.7 & 24.9 & - & 16.9 & 26.3 & 20.0 & 13.8 & 11.0 & 9.8 & 14.5 & 20.8 & 14.9 & 12.8 & 12.3 & 13.9 \\
\hline $50 \mathrm{~cm}$ & 29.4 & 23.2 & - & 24.0 & - & 20.6 & 16.3 & 9.6 & 12.9 & 16.2 & 19.5 & 13.3 & 10.5 & 9.6 & 15.0 \\
\hline
\end{tabular}

of succession: in the 1-2-year-old burned out areas - by 1.1-2.3 times, and in the 10-12-yearolds - by 1.1-1.7 times as compared to the soil moisture in the forest (Table 8, 9, Fig. 4).

And the greater excess of soil moisture on firesites in first year after fire to the forest occurs late in summer (August) when there is a to 2.3-time moisture increase (Table 9). This is due to rise of water from the lower water-saturated horizons of the soil with increasing thickness of the seasonally thawed layer and reduced consumption of water by transpiration to disturbed surface cover of the burning (Pozdnyakov, 1963a; Tarabukina, Savvinov, 1990).

Distribution of moisture in the soil profile at different depths is quite even under the forest canopy, but humidity in the upper horizons is often raised. It is explained by the ability of litter and humus horizon of the soil to retain moisture. There is over-moistened soil in the all burned areas and in the forest at the beginning of the vegetative period (the 1st decade of June). In July-August humidity becomes stable and generally slightly changes. A relative soil drying up is observed due to the consumption of water by trees and grassshrub cover in a $20-30-\mathrm{cm}$ layer in the cowberry larch and a 58-60-year-old burned area. In the middle of the vegetative period the lowest soil moisture is noted: in the fresh burned areas - due to greater evaporation from the exposed surface and in 10-12, 21-23 and 58-60-year-old burned areas - due to absorption of water by roots of larch undergrowth and grass-shrub plants, which grow rapidly especially at this time. The highest water consumption and, consequently, low soil moisture is observed in 21-23-year-old burned out sites with dominant birch-larch young growth in the cover. The birch is known as one of the species that intensively consumes soil moisture, thus partial soil drying may be associated with this property of plants.

Plant transpiration and soil moisture consumption become lower late in the vegetative season, respectively, soil moisture increases, especially in the burned out areas (Savvinov, 1971, 1976). 


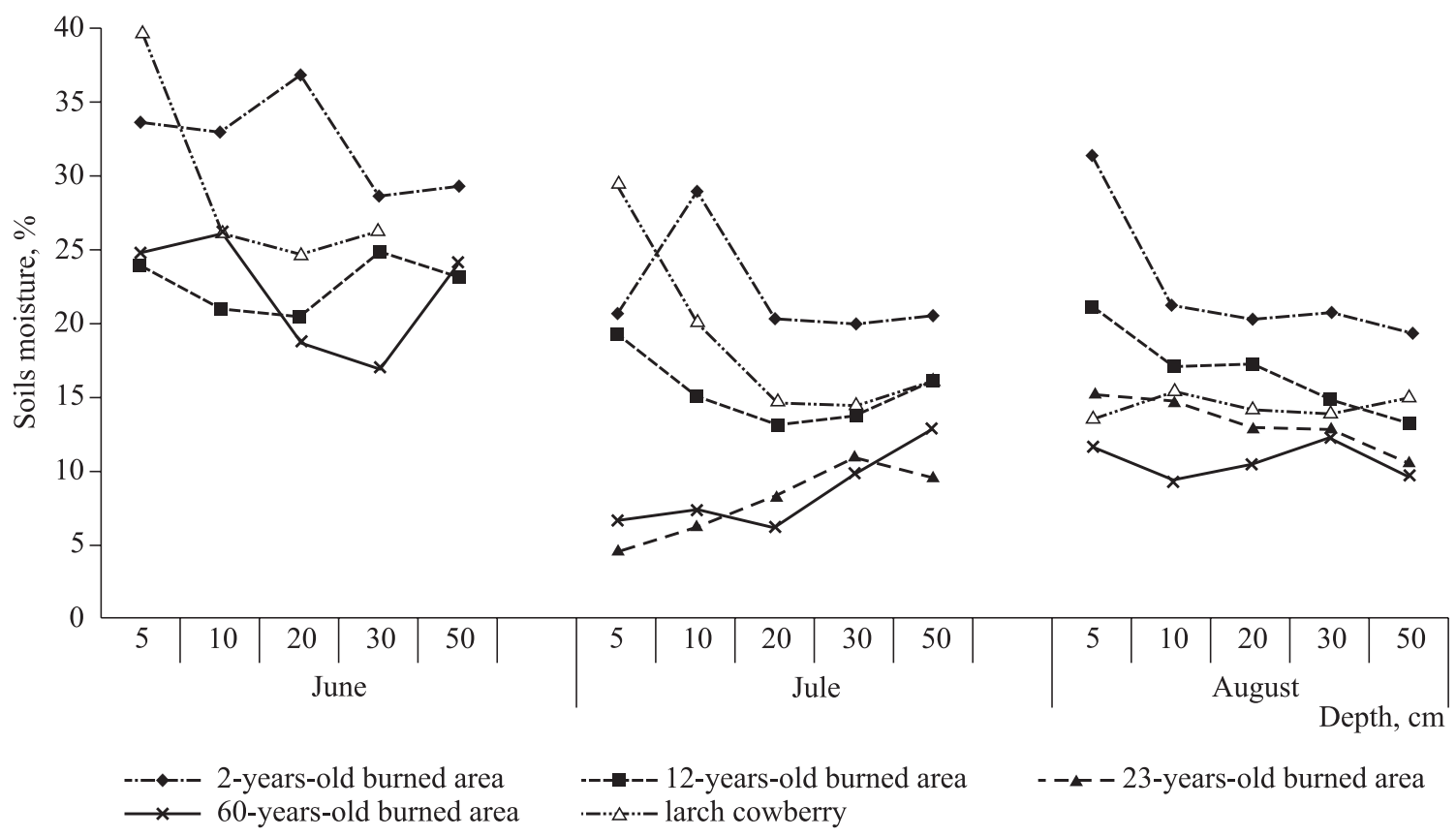

Fig. 4. Field soil moisture at different depths in the burned areas and in cowberry larch (as of 09.06.2004, 17.07.2004, and 29.08.2004).

Calculations showed that moisture of soil increases, basically, at early succession stages: 1-2-year old fire-sites - by 1.1-2.3 times, 10-12-year-old - by 1.1-1.7 times as compared to soil moisture in the forest. And soil overwatering remains on average until the middle succession stages (15-20-year-old fire-sites), after that the so-called «dehydration» of soil occurs lasting till 50 (60) years. Then at late succession stages according to self-thinning of the forest stand stabilization of soil moisture occurs.

Fire impact on permafrost conditions. Permafrost conditions of soils at the burned out areas are significantly different from those in the wooded areas. Soil in the examined recent fire sites thawed to a depth of $89 \mathrm{~cm}$ and under the larch forest only to a depth of $45 \mathrm{~cm}$, early in June, 2002 (Fig. 5).

According to Anatoly I. Utkin (1965), the soil of the fire-sites and coupes in Central Yakutia thaws in $0.4-0.6 \mathrm{~m}$ deeper. According to our records, the soil in fire-sites thawed in average in $0.3-0.8 \mathrm{~m}$ deeper than in the forest $(0.3-0.6 \mathrm{~m}$ in July and $0.4-0.8$ in August). It is explained by the fact that in the first years favorable conditions for intensive soil warming up are created in firesites, that is caused by a good absorption of solar radiation by its black surface and reduction of shading ability of tree crown, in consequence of which the direct solar radiation increases
(Tarabukina, Savvinov, 1990). Considering that the analyzed fire-sites have typical soil features (cryosolic taiga pale-yellow clay-loam soil - in 2, 12-year-old fire-sites and in the forest) distinctions in STL thickness are defined, mostly, by the pattern of the vegetative cover. In this case the statement made by Lev K. Pozdnyakov (1963a) that the vegetative cover and soil properties affect the thawing process, is partially true, because

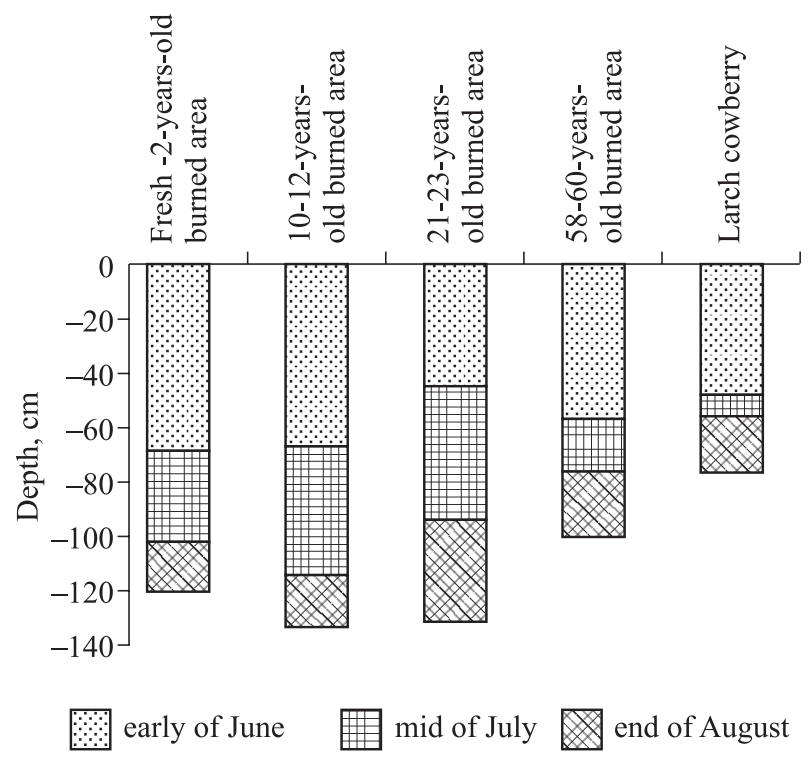

Fig. 5. Depth of seasonal thawing of the soil at different stages of succession of burned out areas and cowberry larch (averages for 2002-2004). 
soil conditions in the examined fire-sites are much similar. And the STL thickness decreases in proportion to vegetation colonization of fire-sites.

The greatest thickness of the thawed layer is observed at the forbs-grasses phase in a 10-12-year-old fire site when the vegetation mainly small grasses - does not prevent the penetration of heat into the ground, the minimum - in the larch forest, where there is the most developed heat insulating layer consisting of thick grass-shrub and moss-lichen cover and litter. The highest rate of soil thawing is typical for a young fire site (10-12 year old). In early June, the difference in the STL thickness between the burned out site and forest was $20-38 \mathrm{~cm}$, late in August it reached $56-78 \mathrm{~cm}$.

The analysis of a 3-year study in fire-sites allowed us to reveal quite significant dependence of the STL depth on the weather conditions, which is in a greater degree affect young fire-sites. 2004 differed from others with its cold weather conditions, lack of hot days in the summer season. For example, comparing the data of a 1-2-yearold fire-site in 2003 and 2004, we can see that in late August in 2004 the STL depth was less $(118 \mathrm{~cm})$ than in $2003(135 \mathrm{~cm})$, the STL depth was $2-17-\mathrm{cm}$ less in the fire-sites and in forest in 2004 than in 2002-2003.

Weather conditions, and in particular, backward summer greatly affected all nature processes, including cryosolic mode of soil. Especially it is visible on the STL thickness in the beginning of the vegetative season (first decade of June) both in the forest and fire-sites.

It should be noted that vegetation regenerates almost completely within 50 years after the fire, and the thickness of permafrost, according to our observation becomes stabilized much slower. Approximately, an inverse pro- cess - soil cooling starts in 20 years after the fire starts in 20 years after the fire, i. e. stabilization of cryosolic soil behavior, whereas right after the fire there is an inverse process - degradation (thawing) of the permafrost level. According to Anatoly P. Abaimov and his co-authors (Abaimov et al., 1996; Prokushkin et al., 2002) in the forests of Central Siberia it occurs in about 16 years after the fire. The difference in the depth location of STL on a 16-year-old burning and larch forest with a wild rosemary-cowberry green moss-lichen carpet is $10-15 \mathrm{~cm}$, while in Central Yakutia it is approximately $55 \mathrm{~cm}(30-80 \mathrm{~cm})$ in a 22-year- old fire site and cowberry larch forest, which is directly dependent on climatic differences, patterns of the permafrost spread and vegetation and fire intensity.

\section{CONCLUSION}

Thus, there always were forest fires in Central Yakutia causing direct or indirect impact on forest ecosystems. It seems practically impossible to prevent fire breaking out in the permafrost regions which are difficult to take under control by the special forest fire protection service because under the conditions of weak decomposition of plant litter and deficient mineralization of organic matter in the soil accumulation of inflammable materials in the forests of the permafrost regions is enough to be the source of forest fire emergence during the arid seasons of the year.

The research carried out showed that significant changes in microclimatic and soil conditions in the burned out areas occur in the first 10 years after the fire. And it is clearly seen especially in the young fire site. All parameters of microclimatic and soil conditions (temperature and soil moisture, STL thickness) depend on the stages of the fire site overgrowing. At the young burned site soil temperature in average increases in comparison with the forest at a depth of $5 \mathrm{~cm}$ in 5.2...5.6 ${ }^{\circ} \mathrm{C}$, at a depth of $30 \mathrm{~cm}-$ in $4.3 \ldots 6.2^{\circ} \mathrm{C}$, soil moisture - by 1.1-2.3 times in a 1-2-year fire site, by 1.1-1.7 times in a 10-12-year-old one; STL thickness is $0.3-0.8 \mathrm{~m}$ greater in the burned areas than in the forest. There is stabilization of the modified conditions in the post-fire period in the course of succession. The process of the soil cooling and freezing begins in 20 year's time after the fire.

\section{REFERENCES}

Abaimov A. P., Prokushkin S. G., Zyryanova O. A. Ekologo-fitoscenoticheskaya oscenka vozdeistviya pozarov na lesa kriolitozony Srednei Sibiri (Ecophytocoenological estimation of wild fires effect on forests of the permafrost zone in Central Siberia) // Sibirskiy Ekologicheskiy Zhurnal (Sib. J. Ecol.). 1996. N. 1. P. 51-60 (in Russian with English abstract).

Bosikov N. P. Evolyusciya alasov scentralnoi Yakutii (Evolution of alases in Central 
Yakutia). Yakutsk: Inst. Permafrost Stud., USSR Acad. Sci., Sib. Br., 1991. 128 p. (in Russian).

Dokhunaev $V$. N. Issledovanie kornevyshch sistem nekotorykh rasteniy Scentral'noy Yakutii v raznykh ekologicheskikh usloviyakh: avtoref. dis. kand. biol. nauk (Investigation of the root systems of some plants in the Central Yakutia in different environmental conditions: candidate of biol. sci. (PhD) thesis). Leningrad, 1963. 20 p. (in Russian).

Dokhunaev $V . N$. Kornevaya sistema rastenii $\mathrm{v}$ merzlotnykh pochvakh Yakutii (The root system of plants in permafrost soils of Yakutia). Yakutsk: Yakut Br. Sib. Div., USSR Acad. Sci., 1988. 176 p. (in Russian).

Furyaev $V$. $V$. Rol' pozharov $\mathrm{v}$ proscesse lesoobrazovaniya (Role of fires in the forest formation process). Novosibirsk: Nauka. Sib. Publ. Comp. Rus. Acad. Sci., 1996. 253 p. (in Russian).

Gavrilova M. K. Teplovoi balans listvennichnogo lesa na Leno-Amginskom mezhdurech'ye (Thermal balance of larch forest in the Lena and Amga interfluve) // Gidroklimaticheskiye issledovaniya v lesakh Sibiri (Hydroclimatic research in the forests of Siberia). Moscow: Nauka, 1967. P. 28-33 (in Russian).

Gavrilova M. K. Radiascionnyi rezhim v listvennichnykh lesakh Yugo-Zapadnoi Yakutii (Radiation regime in larch forests of South-West Yakutia) // Lesovedenie (Rus. J. For. Sci.). 1969. N. 1. P. 16-23 (in Russian with English abstract).

Gavrilova M. K. Klimat Scentral'noi Yakutii (Climate of Central Yakutia). Yakutsk: Yakut Book Publ., 1973. 119 p. (in Russian).

Isaev A. P. Listvennichnye lesa srednetaezhnoi podzony Yakutii i lesovozobnovleniye na vyrubkah (Larch forests of the middle taiga subzone in Yakutia and forest regeneration on logging areas). Candidate agr. sci. (PhD) thesis. Krasnoyarsk: V. N. Sukachev Institute of Forest, Rus. Acad. Sci., Sib. Br., 1993. 23 p. (in Russian).

Isaev A. P., Protopopova V. V., Takahashi K. Istoriya lesnykh pozharov $\mathrm{v}$ okrestnostyakh goroda Yakutska (The history of forest fires in the vicinity of the city of Yakutsk) // Problemy izucheniya rastitelnogo pokrova Yakutii: sbornik nauchnykh statei (Problems of study of the plant cover of Yakutia: collection sci. works). Yakutsk: Sakhapoligrafizdat, 2004. P. 121-126 (in Russian).

Lytkina (Gabysheva) L. P., Isaev A. P. Forest fires // The Far North: plant biodiversity and ecology of Yakutia. Plant and Vegetation 3, Springer Sci. + Business Media B. V. 2010. P. 265-269. DOI 10.1007/978-90-481-3774-9

Pozdnyakov L. K. Gidroklimaticheskii rezhim listvennichnykh lesov Scentral'noi Yakutii (Hydroclimatic regime of larch forests in Central Yakutia). Moscow: USSR Acad. Sci. Publ., 1963a. 146 p. (in Russian).

Pozdnyakov L. K. Gidrologicheskii rezhim listvennichnykh lesov Scentral'noi Yakutii (Hydrologic regime of larch forests in Central Yakutia) // Materialy po izucheniyu lesov Sibiri i Dalnego Vostoka (Materials on study forests of Siberia and Far East). Krasnoyarsk: V. N. Sukachev Institute of Forest and Timber, USSR Acad. Sci., Sib. Br., 1963b. P. 71-77 (in Russian).

Prokushkin S. G., Abaimov A. P., Prokushkin A. S. Temperaturnyi rezhim $\mathrm{v}$ listvennichnikah na merzlotnykh pochvah (Temperature regime in larch forests on permafrost soils) // Lesnye ekosistemy Yeniseiskogo Meridiana (Forest ecosystems of Yenisey Meridian). Novosibirsk: Rus. Acad. Sci., Sib. Br. Publ., 2002. P. 34-45 (in Russian with English abstract).

Prokushkin S. G., Zyryanova O. A. Influence of Gmelin larch trees on postfire restoration of forest communities in the permafrost zone of Central Siberia // Contempor. Probl. Ecol. 2013. N. 5. P. 486-492.

Rode A. A. Osnovy ucheniya o pochvennoy vlage. Metody izucheniya vodnogo rezhima pochv (The basic theory on soil moisture. The methods for studying soil water regime). V. 2. Leningrad: Gidrometeoizdat, 1969. 286 p. (in Russian).

Sannikov S. N. Sciklicheski-eroziino pirogennaya teoriya yestestvennogo vozobnovleniya sosny obyknovennoi (A cyclical-erosion-pyrogenic theory for natural regeneration of Scotch pine) // Ekologiya (Rus. J. Ecol.). 1983. N. 1. P. 3-9 (in Russian).

Savvinov D. D. Temperaturnyi i vodnyi rezhimy lesnykh pochv Yakutii (Temperature and water regimes of forest soils in Yakutia) // Issledovaniya rastitelnosti i pochv $\mathrm{v}$ lesakh Severo-Vostoka SSSR (Vegetation and soil 
studies in forests of the USSR North-East). Yakutsk: Yakutknigoizdat, 1971. P. 118-175 (in Russian).

Savvinov D. D. Gidrotermicheskiy rezhim pochv v zone mnogoletnei merzloty (Gydrothermic regime of soils in the permafrost zone). Novosibirsk: Nauka. Sib. Br., 1976. 254 p. (in Russian).

Scherbakov I. P., Zabelin O. F., Karpel B. A. Lesnye pozhary v Yakutii i ikh vliyaniye na prirodu lesa (Forest fires in Yakutia and their impact on forest nature). Novosibirsk: Nauka. Sib. Br., 1979. 224 p. (in Russian).

Tarabukina V. G., Savvinov D. D. Vliyaniye pozharov na merzlotnye pochvy (Influence of fires on permafrost soils). Novosibirsk: Nauka. Sib. Br., 1990. 120 p. (in Russian).

Timofeyev P. A., Isaev A. P., Scherbakov I. P. Lesa srednetaeznoi podzony Yakutii (Forests of the middle taiga subzone of Yakutia). Yakutsk:
Yakut Sci. Center, Sib. Br., Rus. Acad. Sci., 1994. 140 p. (in Russian).

Utkin A. I. Lesa Scentralnoi Yakutii (Forests of Central Yakutia). Moscow: Nauka, 1965. 208 p. (in Russian).

Yakovlev A. P. Pozharoopasnost' sosnovykh i listvennichnykh lesov (Fire risk of pine and larch forests) // Lesnye pozhary v Yakutii i ikh vliyanie na prirodu lesa (Forest fires in Yakutia and its influence on forest nature). Novosibirsk: Nauka. Sib. Br., 1979. P. 195-212 (in Russian).

Zyabchenko S. S., Zagural'skaya L. M., Lazarev I. $P$. Dinamika ekologicheskikh proscessov na sploshnykh konscentrirovannykh vyrubkah Severnoi Karelii (Dynamics of ecological processes on concentrated clear cuts in North Karelia) // Lesovedenie (Rus. J. For. Sci.). 1988. N. 3. P. 3-10 (in Russian with English abstract). 


\title{
ВЛИЯНИЕ ЛЕСНЫХ ПОЖАРОВ НА МИКРОКЛИМАТИЧЕСКИЕ И ПОЧВЕННЫЕ УСЛОВИЯ ЛЕСОВ КРИОЛИТОЗОНЫ (ЯКУТИЯ, СЕВЕРО-ВОСТОЧНАЯ СИБИРЬ)
}

\author{
(C) 2015 г. Л. П. Габышева ${ }^{1,2}$, А. П. Исаев ${ }^{1,3}$ \\ ${ }^{1}$ Институт биологических проблем криолитозоны СО РАН \\ 677980, Якутск, просп. Ленина, 41 \\ 2 Якутская государственная сельскохозяйственная академия \\ 677980, Якутск, ул. Красильникова, 15 \\ ${ }^{3}$ Институт естественных наук Северо-Восточного Федерального университета \\ им. М. К. Аммосова \\ 677980, Якутск, ул. Кулаковского, 42 \\ E-mail: 1lp77@yandex.ru, forest_forest@ibpc.ysn.ru \\ Поступила в редакцию: 12.08.2015 г.
}

\begin{abstract}
Проанализированы данные о возникновении и частоте пожаров в лесах Центральной Якутии (Северо-Восточной России). Сделаны расчеты связи показателей горимости лесов с социальноэкономическими и климатическими условиями. Выявлена тесная связь количества и плотности населения с горимостью и частотой пожаров (0.95-0.99). Не столь значительная отрицательная связь прослеживается между суммой осадков за пожароопасный период и частотой пожаров $(-0.53)$. Приведены результаты исследования влияния пожаров на микроклиматические и почвенные условия в лесах Центральной Якутии. Проведенные исследования позволили установить, что заметные изменения микроклиматических и почвенных условий на гарях происходят в первые 10 лет после пожара. На молодых гарях температура почвы в среднем увеличивается на глубине 5 см на $5.2 \ldots 5.6^{\circ} \mathrm{C}$, на глубине $30 \mathrm{~cm}-$ на $4.3 \ldots 6.2^{\circ} \mathrm{C}$; влажность почвы на 1-2-летних гарях - в 1.1-2.3 раза, на 10-12-летних - в 1.1-1.7 раза выше; мощность сезонноталого слоя на 0.3-0.8 м больше на гарях, чем в не горевшем лесу. Выявлено, что все параметры микроклиматических и почвенных условий (температура и влажность почвы, глубина сезонноталого слоя) зависят от степени зарастания гари. С течением сукцессионного времени происходит стабилизация измененных после пожаров условий, которая начинается на гарях Центральной Якутии через 20-25 лет после пожара.
\end{abstract}

Ключевые слова: криолитозона, лесные пожары, гари, пожарища, Якутия.

DOI: $10.15372 /$ SJFS20150609 